\title{
Changes in Liver-related Mortality by Etiology and Sequelae: Underlying Versus Multiple Causes of Death
}

\author{
Ming-Jen Sheu \\ Chi Mei Foundation Hospital: Chi Mei Medical Center

\section{Fu-Wen Liang} \\ Kaohsiung Medical University \\ Ching-Yih Lin \\ Chi Mei Foundation Hospital: Chi Mei Medical Center
}

Tsung-Hsueh Lu ( $\nabla$ robertlu@mail.ncku.edu.tw)

Department of Public Health, College of Medicine, National Cheng Kung University, Tainan, Taiwan https://orcid.org/0000-00034715-3787

\section{Research}

Keywords: mortality, cause of death, underlying cause of death, multiple causes of death, burden of disease, liver disease, hepatitis C virus, alcoholic liver disease, cirrhosis, primary liver cancer, secondary liver cancer

Posted Date: October 27th, 2020

DOI: https://doi.org/10.21203/rs.3.rs-96337/v1

License: @ (1) This work is licensed under a Creative Commons Attribution 4.0 International License. Read Full License 


\section{Abstract}

Background: The expanded definition of liver-related deaths includes a wide range of etiologies and sequelae. We compared the changes in liver-related mortality by etiology and sequelae for different age groups between 2008 and 2018 in the United States using both underlying and multiple cause of death (UCOD and MCOD) data.

Methods: We extracted mortality data from the CDC WONDER. Both the absolute (rate difference) and relative (rate ratio and $95 \%$ confidence intervals) changes were calculated to quantify the magnitude of change using the expanded definition of liver-related mortality.

Result: Using the expanded definition including secondary liver cancer and according to UCOD data, we identified 68,037 liver-related deaths among people aged 20 years and above in 2008 (29 per 100,000) and this increased to 90,635 in 2018 (33 per 100,000), a 13\% increase from 2008 to 2018. However, according to MCOD data, the number of deaths was 113,219 (48 per 100,000) in 2008 and increased to 161,312 (58 per 100,000) in 2018, indicating a $20 \%$ increase. The increase according to MCOD was mainly due to increase in alcoholic liver disease and secondary liver cancer (liver metastasis) for each age group and hepatitis C virus (HCV) and primary liver cancer among decedents aged 65-74 years.

Conclusion: The direction of mortality change (increasing or decreasing) was similar in UCOD and MCOD data in most etiologies and sequelae, except secondary liver cancer. However, the extent of change differed between UCOD and MCOD data.

\section{Background}

Cause of death mortality data are the most complete and standardized population-based health data that can be used to estimate the burden of health problems at a national level. Changes in cause-specific mortality can be examined to assess the effectiveness of interventions and identify emergent health problems. Several studies have examined the changes in liver-related mortality in the United States (eg, hepatitis C virus infection [HCV] [1-4], viral hepatitis [5], cholestatic liver disease [6], alcoholic liver disease [7, 8], nonalcoholic fatty liver disease [9], liver cancer [10], chronic liver disease [11], and cirrhosis and liver cancer) [12, 13]. However, these studies only investigated one specific liver disease, which does not provide a comprehensive representation of the complexity of liverrelated mortality, because certifying physicians may record several liver-related diagnoses on death certificates (Fig. 1). Several scholars have suggested using an expanded definition of liver-related deaths, which includes a wide range of etiologies (hepatitis B or C virus infection, or alcoholic or toxic liver disease) and sequelae (liver cancer, cirrhosis, esophageal varices, hepatorenal syndrome, or hepatic failure), to more accurately assess liver-related mortality burden [14-19].

The National Center for Health Statistics' official published mortality data are compiled based on the underlying cause of death (UCOD), which is defined as "(a) the disease or injury which initiated the train of morbid events leading directly to death, or (b) the circumstances of the accident or violence which produced the fatal injury” [20]. If the certifying physician records several liver-related diagnoses, such as HCV in part 2 and cirrhosis, liver cancer, and hepatic failure in part 1 of the death certificate (Fig. 1), then "liver cancer" would be selected as the UCOD according to the international selection rules set by the World Health Organization and thus would be categorized as a liver cancer death in mortality data [20]. Numerous scholars have suggested using multiple cause of death (MCOD) data to make full use of information provided by the certifying physicians [19, 21-28].

Studies have reported a decline in HCV associated mortality since 2014 [4, 11], and a persistent increase in mortality from alcoholic liver disease [8, 11], cirrhosis, and liver cancer [12-13]. However, mortality changes have not been presented by etiology and sequelae for different age groups using both UCOD and MCOD data. Furthermore, previous studies did not include secondary liver cancer (liver metastasis) in the expanded definition. The diagnosis and treatment of liver metastasis require relatively high-cost and multidiscipline inputs (eg, surgical, medical, radiation, and interventional specialties), which should be included in the estimation of mortality burden of liver-related mortality $[29,30]$. This study sought to compare the changes in liver-related mortality by etiology and sequelae for different age groups from 2008 to 2018 in the United States using UCOD and MCOD data.

\section{Methods}

UCOD and MCOD mortality data were extracted from the Center for Disease Control and Prevention Wide-ranging Online Data for Epidemiologic Research (CDC WONDER) for 2008 and 2018 [31]. The International Statistical Classification of Diseases and Related 
Health Problems, Tenth Revision (ICD-10) codes for the expanded definition of liver-related deaths are based on those in the study of Asrani et al [17], as illustrated in Table 1.

Table 1

ICD-10 codes for liver-related disease

\begin{tabular}{|ll|}
\hline Liver-related disease & ICD-10 codes \\
\hline Hepatitis C virus & B171, B182 \\
\hline Other hepatitis & B15, B16, B170, B172, B178, B179, B180, B181, B188, B189, B19, K73 \\
\hline Primary liver cancer & C22 \\
\hline Secondary liver cancer & C787 \\
\hline Esophageal varices & I85 \\
\hline Alcoholic liver disease & K70 \\
\hline Hepatic failure & K72 \\
\hline Liver cirrhosis & K74 \\
\hline Other diseases of liver (toxic, inflammatory, and others) & K71, K75, K76 \\
\hline ICD-10, International Statistical Classification of Diseases and Related Problems Tenth Revision \\
\hline
\end{tabular}

Decedents aged 20 years and over were included. Age-specific liver-related mortality rates were calculated for the age groups of 20$44,45-64,65-74$, and $\geq 75$ years, and age-standardized death rates (ASDR) were calculated using the age structure of the United States population for 2000 as the standard population. Both the absolute (rate difference) and relative (rate ratio and $95 \%$ confidence intervals) changes were calculated to quantify the magnitude of change from 2008 to 2018 for overall and specific liver-related mortality rates.

These calculations were performed using UCOD and MCOD data separately. The decedent in Fig. 1 would be categorized as one liver cancer death using the UCOD approach, whereas they would be categorized as one death with HCV, one death with cirrhosis, one death with liver cancer, and one death with hepatic failure if the MCOD approach was used. However, for overall liver-related deaths in MCOD data, the decedent in Fig. 1 would be counted as one death only. The percentage of UCOD/MCOD deaths was calculated to reflect the contribution of MCOD in the increase in the number of deaths.

\section{Results}

Using the expanded definition including secondary liver cancer and according to UCOD data, we identified 68,037 liver-related deaths among people aged 20 years and above in 2008 (ASDR was 29 per 100,000) and this increased to 90,635 in 2018 (ASDR was 33 per 100,000), a 13\% increase from 2008 to 2018. However, according to MCOD data, the number of deaths was 113,219 (ASDR was 48 per 100,000) in 2008 and increased to 161,312 (ASDR was 58 per 100,000) in 2018, indicating a $20 \%$ increase. If we excluded secondary liver cancer the percentage of increase was 14\%, from 42 per 100,000 (98,657 deaths) in 2008 to 48 per 100000 (133,216 deaths) in 2018.

The rate differences and rate ratios from 2008 to 2018 for overall and specific etiology and sequelae are summarized in Table 2 and Fig. 2 Mortality associated with HCV exhibited the largest decline according to both UCOD and MCOD data, followed by other hepatitis and hepatic failure. Mortality associated with alcoholic liver disease exhibited the largest increase, followed by primary liver cancer. Mortality from secondary liver cancer (liver metastasis) decreased according to UCOD data but increased according to MCOD data. The UCOD/MCOD percentage was the highest for primary liver cancer (92\% in 2008 and $91 \%$ in 2018), followed by alcoholic liver disease (76\% in 2008 and $76 \%$ in 2018), and was the lowest for esophageal varices (6.9\% in 2008 and $5.8 \%$ in 2018), followed by secondary liver cancer (11.9\% in 2008 and $6.6 \%$ in 2018). 
Table 2

Age-Standardized Death Rate of Liver-Related Disease in 2008 and 2018 According to Underlying and Multiple Cause of Death (UCOD and MCOD) Data

\begin{tabular}{|c|c|c|c|c|c|c|c|}
\hline & 2008 & & 2018 & & Rate & & \\
\hline Liver-related disease & Deaths & Rate & Deaths & Rate & Difference & Ratio & $(95 \% \mathrm{Cl})$ \\
\hline \multicolumn{8}{|l|}{ Overall } \\
\hline UCOD & 68,037 & 28.8 & 90,635 & 32.5 & 3.6 & 1.13 & $(1.11-1.13)$ \\
\hline MCOD & 113,219 & 48.2 & 161,312 & 57.6 & 9.5 & 1.20 & $(1.18-1.20)$ \\
\hline UCOD/MCOD, \% & 60.1 & & 56.2 & & & & \\
\hline \multicolumn{8}{|c|}{ Overall (excluding secondary liver cancer) } \\
\hline UCOD & 66,175 & 28.0 & 88,785 & 31.8 & 3.80 & 1.14 & $(1.12-1.14)$ \\
\hline MCOD & 98,657 & 41.8 & 133,216 & 47.7 & 5.88 & 1.14 & $(1.13-1.14)$ \\
\hline UCOD/MCOD, \% & 67.1 & & 66.6 & & & & \\
\hline \multicolumn{8}{|l|}{ Etiology } \\
\hline \multicolumn{8}{|l|}{ Hepatitis $C$ virus } \\
\hline UCOD & 6834 & 2.8 & 4127 & 1.5 & -1.3 & 0.52 & $(0.50-0.54)$ \\
\hline MCOD & 15,707 & 6.4 & 15,712 & 5.6 & -0.9 & 0.86 & $(0.84-0.88)$ \\
\hline UCOD/MCOD, \% & 43.5 & & 26.3 & & & & \\
\hline \multicolumn{8}{|l|}{ Other hepatitis } \\
\hline UCOD & 883 & 0.4 & 755 & 0.3 & -0.1 & 0.74 & $(0.66-0.80)$ \\
\hline MCOD & 2280 & 1.0 & 2381 & 0.9 & -0.1 & 0.90 & $(0.84-0.94)$ \\
\hline UCOD/MCOD, \% & 38.7 & & 31.7 & & & & \\
\hline \multicolumn{8}{|l|}{ Alcoholic liver disease } \\
\hline UCOD & 14,864 & 6.2 & 23,171 & 8.6 & 2.4 & 1.38 & $(1.35-1.40)$ \\
\hline MCOD & 19,530 & 8.2 & 30,446 & 11.2 & 3.1 & 1.37 & $(1.34-1.39)$ \\
\hline UCOD/MCOD, \% & 76.1 & & 76.1 & & & & \\
\hline \multicolumn{8}{|l|}{ Other diseases of liver } \\
\hline UCOD & 6077 & 2.6 & 8507 & 3.0 & 0.4 & 1.17 & $(1.13-1.20)$ \\
\hline MCOD & 15,394 & 6.6 & 22,228 & 8.0 & 1.4 & 1.22 & $(1.19-1.24)$ \\
\hline UCOD/MCOD, \% & 39.5 & & 38.3 & & & & \\
\hline \multicolumn{8}{|l|}{ Sequelae } \\
\hline \multicolumn{8}{|l|}{ Primary liver cancer } \\
\hline UCOD & 18,159 & 7.8 & 27,647 & 9.7 & 1.9 & 1.24 & $(1.22-1.26)$ \\
\hline MCOD & 19,666 & 8.4 & 30,441 & 10.7 & 2.2 & 1.27 & $(1.24-1.28)$ \\
\hline UCOD/MCOD, \% & 92.3 & & 90.8 & & & & \\
\hline \multicolumn{8}{|l|}{ Secondary liver cancer } \\
\hline UCOD & 2071 & 0.9 & 2104 & 0.7 & -0.2 & 0.82 & $(0.76-0.86)$ \\
\hline MCOD & 17,341 & 7.5 & 31,676 & 11.2 & 3.7 & 1.49 & $(1.46-1.51)$ \\
\hline
\end{tabular}




\begin{tabular}{|llllllll|}
\hline & 2008 & \multicolumn{7}{c|}{ 2018 } & & & \\
\hline UCOD/MCOD, \% & 11.9 & & 6.6 & & & & \\
\hline Cirrhosis & & & & & & & \\
\hline UCOD & 14,993 & 6.4 & 19,615 & 7.0 & 0.6 & 1.09 & $(1.07-1.11)$ \\
\hline MCOD & 30,463 & 12.9 & 43,165 & 15.3 & 2.4 & 1.18 & $(1.16-1.20)$ \\
\hline UCOD/MCOD, \% & 49.2 & & 45.4 & & & & \\
\hline Esophageal varices & & & & & & & \\
\hline UCOD & 181 & 0.1 & 211 & 0.1 & 0.0 & 1.00 & $(0.80-1.19)$ \\
\hline MCOD & 2619 & 1.1 & 3663 & 1.3 & 0.2 & 1.22 & $(1.15-1.27)$ \\
\hline UCOD/MCOD, \% & 6.9 & & 5.8 & & & & \\
\hline Hepatic failure & & & & & & & \\
\hline UCOD & 3975 & 1.7 & 4498 & 1.6 & -0.1 & 0.96 & $(0.91-0.99)$ \\
\hline MCOD & 24,578 & 10.5 & 27,059 & 9.7 & -0.7 & 0.93 & $(0.91-0.94)$ \\
\hline UCOD/MCOD, \% & 16.2 & & 16.6 & & & & \\
\hline
\end{tabular}

The age differences in rate differences and rate ratios from 2008 to 2018 for overall and specific etiology and sequelae are reported in Table 3. For alcoholic liver disease, we noted increase in each age group according to both UCOD and MCOD. For secondary liver cancer increase in each age group occurred only in MCOD not in UCOD. For primary liver cancer, the increase confined to decedents aged 65-74 years old in both UCOD and MCOD. For HCV, only decedents aged 65-74 years old showed increase change according to MCOD only. The figures of mortality changes by age could be viewed in https://public.tableau.com/profile/robert.lu\#!/vizhome/20072017USA/Liver-relatedmortality 
Table 3

Liver-related disease death rate difference (RD) and rate ratio (RR) and 95\% confidence intervals (95\% Cl) between 2008 and 2018 according to underlying and multiple causes of death (UCOD and MCOD) data

\begin{tabular}{|c|c|c|c|c|c|c|c|c|c|c|c|c|}
\hline \multirow[b]{2}{*}{$\begin{array}{l}\text { Liver- } \\
\text { related } \\
\text { disease }\end{array}$} & \multicolumn{3}{|c|}{$20-44$ years } & \multicolumn{3}{|c|}{ 45-64 years } & \multicolumn{3}{|c|}{$65-74$ years } & \multicolumn{3}{|c|}{$75+$ years } \\
\hline & $\mathrm{RD}$ & $\mathrm{RR}$ & $\begin{array}{l}(95 \% \\
\mathrm{Cl})\end{array}$ & $\mathrm{RD}$ & $\mathrm{RR}$ & $\begin{array}{l}(95 \% \\
\mathrm{Cl})\end{array}$ & $\mathrm{RD}$ & $\mathrm{RR}$ & $\begin{array}{l}(95 \% \\
\mathrm{Cl})\end{array}$ & $\mathrm{RD}$ & $\mathrm{RR}$ & $\begin{array}{l}(95 \% \\
\mathrm{Cl})\end{array}$ \\
\hline \multicolumn{13}{|l|}{ Overall } \\
\hline UCOD & 0.52 & 1.11 & $\begin{array}{l}(1.06- \\
1.15)\end{array}$ & 2.89 & 1.06 & $\begin{array}{l}(1.04- \\
1.08)\end{array}$ & 18.24 & 1.29 & $\begin{array}{l}(1.26- \\
1.31)\end{array}$ & 9.65 & 1.12 & $\begin{array}{l}(1.09- \\
1.13)\end{array}$ \\
\hline MCOD & 0.98 & 1.13 & $\begin{array}{l}(1.09- \\
1.15)\end{array}$ & 9.38 & 1.14 & $\begin{array}{l}(1.12- \\
1.14)\end{array}$ & 37.26 & 1.34 & $\begin{array}{l}(1.31- \\
1.35)\end{array}$ & 32.15 & 1.21 & $\begin{array}{l}(1.19- \\
1.22)\end{array}$ \\
\hline \multicolumn{13}{|c|}{ Overall (excluding secondary liver cancer) } \\
\hline UCOD & 0.54 & 1.11 & $\begin{array}{l}(1.07- \\
1.15)\end{array}$ & 2.81 & 1.06 & $\begin{array}{l}(1.04- \\
1.07)\end{array}$ & 18.59 & 1.31 & $\begin{array}{l}(1.27- \\
1.33)\end{array}$ & 11.48 & 1.15 & $\begin{array}{l}(1.12- \\
1.17)\end{array}$ \\
\hline MCOD & 0.56 & 1.07 & $\begin{array}{l}(1.04- \\
1.10)\end{array}$ & 4.69 & 1.07 & $\begin{array}{l}(1.06- \\
1.08)\end{array}$ & 28.44 & 1.31 & $\begin{array}{l}(1.28- \\
1.33)\end{array}$ & 18.67 & 1.16 & $\begin{array}{l}(1.13- \\
1.17)\end{array}$ \\
\hline \multicolumn{13}{|l|}{ Etiology } \\
\hline \multicolumn{13}{|c|}{$\begin{array}{l}\text { Hepatitis C } \\
\text { virus }\end{array}$} \\
\hline UCOD & -0.26 & 0.37 & $\begin{array}{l}(0.30- \\
0.43)\end{array}$ & -3.43 & 0.47 & $\begin{array}{l}(0.44- \\
0.48)\end{array}$ & -0.21 & 0.94 & $\begin{array}{l}(0.85- \\
1.03)\end{array}$ & -1.54 & 0.54 & $\begin{array}{l}(0.46- \\
0.60)\end{array}$ \\
\hline MCOD & -0.31 & 0.68 & $\begin{array}{l}(0.61- \\
0.74)\end{array}$ & -3.74 & 0.75 & $\begin{array}{l}(0.72- \\
0.76)\end{array}$ & 6.24 & 1.75 & $\begin{array}{l}(1.65- \\
1.85)\end{array}$ & -1.64 & 0.77 & $\begin{array}{l}(0.71- \\
0.83)\end{array}$ \\
\hline \multicolumn{13}{|c|}{$\begin{array}{l}\text { Other } \\
\text { hepatitis }\end{array}$} \\
\hline UCOD & -0.01 & 0.86 & $\begin{array}{l}(0.60- \\
1.11)\end{array}$ & -0.19 & 0.69 & $\begin{array}{l}(0.59- \\
0.77)\end{array}$ & -0.10 & 0.85 & $\begin{array}{l}(0.65- \\
1.03)\end{array}$ & -0.28 & 0.71 & $\begin{array}{l}(0.55- \\
0.86)\end{array}$ \\
\hline MCOD & -0.03 & 0.88 & $\begin{array}{l}(0.72- \\
1.04)\end{array}$ & -0.36 & 0.79 & $\begin{array}{l}(0.72- \\
0.84)\end{array}$ & 0.34 & 1.20 & $\begin{array}{l}(1.04- \\
1.35)\end{array}$ & -0.08 & 0.96 & $\begin{array}{l}(0.82- \\
1.09)\end{array}$ \\
\hline \multicolumn{13}{|c|}{$\begin{array}{l}\text { Alcoholic } \\
\text { liver } \\
\text { disease }\end{array}$} \\
\hline UCOD & 0.90 & 1.43 & $\begin{array}{l}(1.35- \\
1.51)\end{array}$ & 4.45 & 1.36 & $\begin{array}{l}(1.32- \\
1.39)\end{array}$ & 4.33 & 1.43 & $\begin{array}{l}(1.35- \\
1.50)\end{array}$ & 1.49 & 1.31 & $\begin{array}{l}(1.19- \\
1.41)\end{array}$ \\
\hline MCOD & 1.05 & 1.40 & $\begin{array}{l}(1.33- \\
1.47)\end{array}$ & 5.41 & 1.33 & $\begin{array}{l}(1.29- \\
1.35)\end{array}$ & 6.87 & 1.52 & $\begin{array}{l}(1.45- \\
1.58)\end{array}$ & 2.64 & 1.40 & $\begin{array}{l}(1.30- \\
1.50)\end{array}$ \\
\hline \multicolumn{13}{|c|}{$\begin{array}{l}\text { Other } \\
\text { diseases of } \\
\text { liver }\end{array}$} \\
\hline UCOD & -0.10 & 0.82 & $\begin{array}{l}(0.71- \\
0.91)\end{array}$ & -0.09 & 0.98 & $\begin{array}{l}(0.92- \\
1.02)\end{array}$ & 2.42 & 1.41 & $\begin{array}{l}(1.31- \\
1.51)\end{array}$ & 3.60 & 1.49 & $\begin{array}{l}(1.38- \\
1.58)\end{array}$ \\
\hline MCOD & 0.03 & 1.02 & $\begin{array}{l}(0.94- \\
1.08)\end{array}$ & 0.64 & 1.07 & $\begin{array}{l}(1.03- \\
1.09)\end{array}$ & 6.32 & 1.45 & $\begin{array}{l}(1.38- \\
1.50)\end{array}$ & 7.66 & 1.43 & $\begin{array}{l}(1.37- \\
1.49)\end{array}$ \\
\hline \multicolumn{13}{|c|}{ Sequelae } \\
\hline \multicolumn{13}{|c|}{$\begin{array}{l}\text { Primary } \\
\text { liver cancer }\end{array}$} \\
\hline UCOD & 0.01 & 1.03 & $\begin{array}{l}(0.89- \\
1.15)\end{array}$ & 1.74 & 1.19 & $\begin{array}{l}(1.15- \\
1.22)\end{array}$ & 10.03 & 1.50 & $\begin{array}{l}(1.44- \\
1.55)\end{array}$ & 5.31 & 1.15 & $\begin{array}{l}(1.11- \\
1.18)\end{array}$ \\
\hline
\end{tabular}




\begin{tabular}{|c|c|c|c|c|c|c|c|c|c|c|c|c|}
\hline \multirow[b]{2}{*}{ MCOD } & \multicolumn{3}{|c|}{$20-44$ years } & \multicolumn{3}{|c|}{ 45-64 years } & \multicolumn{3}{|c|}{$65-74$ years } & \multicolumn{3}{|c|}{$75+$ years } \\
\hline & 0.00 & 1.00 & $\begin{array}{l}(0.87- \\
1.13)\end{array}$ & 2.11 & 1.21 & $\begin{array}{l}(1.17- \\
1.24)\end{array}$ & 11.37 & 1.53 & $\begin{array}{l}(1.47- \\
1.57)\end{array}$ & 6.56 & 1.17 & $\begin{array}{l}(1.13- \\
1.21)\end{array}$ \\
\hline \multicolumn{13}{|c|}{$\begin{array}{l}\text { Secondary } \\
\text { liver cancer }\end{array}$} \\
\hline UCOD & -0.02 & 0.46 & $\begin{array}{l}(0.20- \\
0.71)\end{array}$ & 0.05 & 1.08 & $\begin{array}{l}(0.95- \\
1.21)\end{array}$ & -0.25 & 0.89 & $\begin{array}{l}(0.78- \\
0.99)\end{array}$ & -1.78 & 0.69 & $\begin{array}{l}(0.62- \\
0.75)\end{array}$ \\
\hline MCOD & 0.31 & 1.56 & $\begin{array}{l}(1.40- \\
1.72)\end{array}$ & 4.73 & 1.67 & $\begin{array}{l}(1.61- \\
1.72)\end{array}$ & 9.87 & 1.44 & $\begin{array}{l}(1.39- \\
1.49)\end{array}$ & 13.96 & 1.38 & $\begin{array}{l}(1.33- \\
1.42)\end{array}$ \\
\hline \multicolumn{13}{|c|}{ Cirrhosis } \\
\hline UCOD & 0.01 & 1.01 & $\begin{array}{l}(0.91- \\
1.10)\end{array}$ & 0.62 & 1.07 & $\begin{array}{l}(1.03- \\
1.10)\end{array}$ & 1.91 & 1.12 & $\begin{array}{l}(1.06- \\
1.16)\end{array}$ & 2.79 & 1.13 & $\begin{array}{l}(1.08- \\
1.17)\end{array}$ \\
\hline MCOD & 0.00 & 1.00 & $\begin{array}{l}(0.93- \\
1.06)\end{array}$ & 1.77 & 1.09 & $\begin{array}{l}(1.06- \\
1.11)\end{array}$ & 10.97 & 1.35 & $\begin{array}{l}(1.30- \\
1.38)\end{array}$ & 9.97 & 1.25 & $\begin{array}{l}(1.21- \\
1.29)\end{array}$ \\
\hline \multicolumn{13}{|c|}{$\begin{array}{l}\text { Esophageal } \\
\text { varices }\end{array}$} \\
\hline UCOD & -0.01 & 0.74 & $\begin{array}{l}(0.28- \\
1.19)\end{array}$ & 0.01 & 1.11 & $\begin{array}{l}(0.80- \\
1.40)\end{array}$ & 0.01 & 1.05 & $\begin{array}{l}(0.54- \\
1.55)\end{array}$ & -0.01 & 0.93 & $\begin{array}{l}(0.49- \\
1.37)\end{array}$ \\
\hline MCOD & 0.01 & 1.04 & $\begin{array}{l}(0.88- \\
1.19)\end{array}$ & 0.36 & 1.17 & $\begin{array}{l}(1.09- \\
1.24)\end{array}$ & 0.96 & 1.58 & $\begin{array}{l}(1.37- \\
1.77)\end{array}$ & 0.39 & 1.24 & $\begin{array}{l}(1.05- \\
1.41)\end{array}$ \\
\hline \multicolumn{13}{|c|}{$\begin{array}{l}\text { Hepatic } \\
\text { failure }\end{array}$} \\
\hline UCOD & 0.00 & 1.00 & $\begin{array}{l}(0.84- \\
1.14)\end{array}$ & -0.28 & 0.89 & $\begin{array}{l}(0.83- \\
0.94)\end{array}$ & 0.12 & 1.03 & $\begin{array}{l}(0.93- \\
1.12)\end{array}$ & 0.06 & 1.01 & $\begin{array}{l}(0.92- \\
1.10)\end{array}$ \\
\hline MCOD & 0.06 & 1.03 & $\begin{array}{l}(0.96- \\
1.09)\end{array}$ & -1.23 & 0.92 & $\begin{array}{l}(0.89- \\
0.94)\end{array}$ & -1.03 & 0.96 & $\begin{array}{l}(0.92- \\
0.99)\end{array}$ & -3.35 & 0.89 & $\begin{array}{l}(0.85- \\
0.92)\end{array}$ \\
\hline
\end{tabular}

\section{Discussion}

This national population-based study compared the changes in liver-related mortality by etiology and sequelae among different age groups from 2008 to 2018 in the United States using the expanded definition (including secondary liver cancer) and according to both UCOD and MCOD data. The direction of mortality change (increasing or decreasing) was similar in UCOD and MCOD data in most etiologies and sequelae, except secondary liver cancer. However, the extent of change differed between UCOD and MCOD data. The magnitude of decreasing changes in HCV mortality was more prominent in UCOD data than MCOD, particularly for decedents aged 65-74 years (baby boomers born 1945-1965). However, the extent of increasing changes was more drastic in MCOD data than in UCOD data for esophageal varices, cirrhosis, and other diseases of the liver. The magnitude of increasing changes in UCOD and MCOD data was similar for primary liver cancer and alcoholic liver disease.

Kim et al [11] examined four etiology-based mortality changes according to UCOD and MCOD data. Their study indicated a mild reduction of mortality for the hepatitis C virus infection from 2007 to 2014 according to UCOD data, with an annual percentage change (APC) of $-0.4 \%$, followed by a prominent decreasing trend in the APC of $-13.7 \%$ from 2014 to 2016 . A different pattern of change was observed using MCOD data; the APC was $2.0 \%$ from 2007 to 2014 and $-6.4 \%$ from 2014 to 2016 . For alcoholic liver disease, the magnitude of mortality changes was similar according to UCOD and MCOD data; the APC was 5.3\% and 5.5\% from 2014 to 2016, respectively. Kim et al further examined mortality changes from 2007 to 2016 for liver-related sequelae (ie, cirrhosis and liver cancer) and observed APCs of $2.3 \%$ and $2.0 \%$, respectively [13].

We extended the study of Kim and colleagues to examine mortality changes by four age groups. We observed a huge increase in mortality in $\mathrm{HCV}$ (rate ratio was 1.75 with $95 \% \mathrm{Cl} 1.65-1.85$ ) and primary liver cancer (rate ratio was 1.53 with $95 \% \mathrm{Cl} 1.47-1.57$ ) according to MCOD occurred only in decedents aged 65-74 years old and not in other age group. This age specific change was mainly due to the aging of baby boomers [32]. 
Another new finding of this study is the $50 \%$ increase in the number of deaths from secondary liver cancer (liver metastasis) according to MCOD data, from 17,346 in 2008 to 31,689 in 2018. The liver is the most common site for gastrointestinal tumor metastasis because of the mesenteric venous outflow through the portal vein. The most common liver metastasis is colorectal cancer, which is the third leading cancer cause of death in the United States. Approximately $15-20 \%$ of patients with colorectal cancer have synchronous liver metastases at presentation and $50 \%$ eventually develop liver metastases. Metastatic disease in the liver is also commonly observed in lung cancer, neuroendocrine tumors, gastrointestinal stromal tumors, breast cancer, gastric cancer, melanoma, and pancreatic cancer [29, 30,33-35]. However, no study has used mortality data to examine the changes in liver metastasis mortality. Further studies are needed to clarify the epidemiology of liver metastasis-associated mortality, including the distribution of original sites.

One of the strengths of this study is the comparison of the mortality changes using both UCOD and MCOD, which provided a more comprehensive overview of the complexity of liver-related mortality. Piffaretti et al indicated that numerous people die from more than one disease in an aging society. The exclusive use of the UCOD approach may discard useful information on the contribution of other conditions to death [26]. A US study calculated the percentage of UCOD/MCOD deaths among 50 ranked causes of death in 2000 and 2001 and reported five causes (measles, suicide, homicide, legal intervention, and meningococcal infection) with percentages higher than $95 \%$ and six causes (certain kidney conditions [nephritis, nephrotic syndrome, nephrosis], hyperplasia of prostate, nutritional deficiencies, anemia, complications of medical and surgical care, and essential hypertension and hypertensive renal diseases) with percentages lower than $20 \%$. The UCOD/MCOD percentage was $65 \%$ for chronic liver disease and cirrhosis and $50 \%$ for viral hepatitis [23]. The percentage of UCOD/MCOD deaths caused by liver-related etiologies and sequelae in this study was the highest for primary liver cancer (90.8\% in 2018) and was the lowest for esophageal varices and secondary liver cancer (5.8\% and 6.8\% in 2018, respectively). Therefore, detecting the changes in sequelae-associated mortality with a low percentage would be difficult without MCOD data. Fedeli et al had revealed the differences in mortality pattern between those according to standard statistics with those according to MCOD based on different definitions in the Veneto Region in northeastern Italy $[19,24,27]$.

However, MCOD data also has limitations. Piffaretti et al indicated that the statistical unit used for MCOD is the cause of death rather than the death itself, which raises questions regarding the interpretation [26]. For instance, the decedent in Fig. 1 would be counted as one death for hepatic failure, one death for primary liver cancer, one death for cirrhosis, and one death for HCV but only one death in overall liver-related death to avoid duplication in counting the number of death. Piffaretti et al suggested assigning weights to each cause of death reported on the death certificate with the sum of the weights for each death being 1 . The cause-specific mortality rate estimated according to the MCOD weighting approach would increase for certain diagnoses (eg, $43 \%$ for alcohol abuse, $44 \%$ for rheumatoid arthritis and osteoarthrosis, and 19\% for viral hepatitis) [26]. Further studies are needed to examine the effects of using the MCOD weighting approach to investigate liver-related etiologies and sequelae.

Several limitations should be considered when interpreting the findings of this study. First, studies that have examined the information recorded on the death certificate with medical records have suggested underreporting of certain liver-related etiologies and sequelae on the death certificate [16-18]. However, as our primary aim was to examine the changes in liver-related mortality, a systemic bias between 2008 and 2018 caused by underreporting is unlikely. The recommendation of HCV screening in 2012 [36] and the introduction of DAA in 2013 would have increased the reporting of HCV by certifying physicians on the death certificate from 2008 to 2018. Therefore, the extent of decline of recordings of comorbid HCV and liver cancer or cirrhosis among baby boomers from 2008 to 2018 estimated in this study would be underestimated. That to say, the true magnitude of decline would be larger than we estimated.

Furthermore, we argue that death certificates are not documentation recording all the diseases the decedents had, but recording only the diseases or conditions directly leading to death or contributions to the chain of events according to the certifying physician's judgment [37]. The certifying physician is most frequently the attending physician of the decedent and is thus in the optimal position to determine the diseases or conditions that should be recorded. The reviewers who examined the documented medical record in the retrospective study might not have been in a better position to judge which diseases or conditions should be recorded on the death certificate.

Second, to avoid complexity in presentation, we did not examine all combinations among different etiologies and sequelae. According to the study of Ly et al., there were more than 20 combinations among five etiologies, including hepatitis $B$ and $C$ virus, alcoholic liver disease, and nonalcoholic steatohepatitis/fatty liver disease [18]. Including five liver-related sequelae (primary and secondary liver cancer, cirrhosis, esophageal varices, and hepatic failure) would result in just under 100 combinations. In this study, we presented only two crucial combinations (ie, HCV with liver cancer and HCV with cirrhosis). Third, to avoid the complexity of presentation, we did not

Page 8/12 
analyze data for each year from 2008 to 2018, and we did not further analyze differences in sex and ethnicity. Fourth, information on the severity of sequelae is not available on the death certificate. Some people with esophageal varices or liver metastasis might have required large amounts of medical care resources, whereas others did not. There are numerous modules in the treatment of liver metastasis, with large variations in costs; thus, using mortality data alone cannot accurately estimate the healthcare resources used.

\section{Conclusion}

Despite the above-mentioned limitations, we can firmly conclude that presenting the mortality changes using both UCOD and MCOD data by etiology and sequelae and by age could provide a more comprehensive overview of the complexity of liver-related mortality, particularly for baby boomers (born during 1945-1965), because they exhibit a high prevalence of HCV. The findings of this study indicated a decline in mortality associated with HCV from 2008 to 2018, particularly among baby boomers, suggesting an effect of the change in screening recommendations in 2012 and the introduction of DDA in late 2013. However, we also observed a persistent increase in alcohol-related liver disease mortality from 2008 to 2018. Several scholars have urged interventions this emergent public health problem $[8,11,38,39]$.

\section{Abbreviations}

\section{CDC WONDER}

The Center for Disease Control and Prevention Wide-ranging Online Data for Epidemiologic Research; HCV:Hepatitis C virus; ICD10:The International Statistical Classification of Diseases and Related Health Problems, Tenth Revision; MCOD:Multiple causes of death; UCOD:Underlying cause of death

\section{Declarations}

\section{Acknowledgements}

Not applicable.

\section{Authors' contributions}

Study design, analysis and interpretation of the data, and drafting and critical review of the manuscript: MJH, FWL, CYL, and THL. All authors read and approved the final manuscript.

\section{Funding}

This study was supported by the Chi-Mei \& National Cheng Kung University Joint Program (CMNCKU10309).

Availability of data and materials

The datasets used and/or analyzed during the current study are available from the corresponding author on reasonable request.

\section{Ethics approval and consent to participate}

This study was approved by the Institutional Review Board of National Cheng Kung University Hospital as exemption of review because of using public open data.

\section{Consent for publication}

Not applicable.

\section{Competing interests}

The authors have no competing conflicts of interest regarding this manuscript.

\section{References}


1. Kim ER. The burden of hepatitis C in the United States. 2002;36:S30-4.

2. Wise M, Bialek S, Finelli L, et al. Changing trends in hepatitis C-related mortality in the UnitedStates, 1995-2004. Hepatology. 2008;47:1128-

3. Ly KN, Hughes EM, Jiles RB, et al. Rising mortality associated with hepatitis C virus in the UnitedStates, 2003-2013. Clin Infect Dis. 2016;62:1287-

4. Ly KN, Minino AM, Liu SJ, et al. Deaths associated with hepatitis C virus infection among residents in 50 States and the District of Columbia, 2016-2017. Clin Infect Dis. 2020;71:1149-60.

5. Ly KN, Xing J, Klevens RM, et al. The increasingburden of mortality from viralhepatitis in the UnitedStates between 1999 and 2007. Ann Intern Med. 2012;156:271-

6. Mendes FD, Kim WR, Pedersen R, et al. Mortality attributable to cholestatic liver disease in the United States. Hepatology. 2008;47:1241-

7. Paula H1, Asrani SK, Boetticher NC, et al.Alcoholicliverdisease-relatedmortality in the UnitedStates: 1980-2003. Am J Gastroenterol. 2010;105:1782-

8. Moon AM, Yang JY, Barritt IV AS, et al. Rising mortality from alcohol-associated liver disease in the United States in the 21 st Century. Am J Gastroenterol. 2020;115:79-

9. Paik JM, Henry L, De Avila L, et al. Mortality related to nonalcoholic fatty liver disease is increasing in the United States. Hepatol Commun. 2019;3:1459-71.

10. Altekruse SF, Henley SJ, Cucinelli JE, et al. Changing hepatocellular carcinoma incidence and liver cancer mortality rates in the United States. Am J Gastroenterol. 2014;109:542-

11. Kim D, Li AA, Gadiparthi C, et al. Changing trends in etiology-based annual mortality from chronic liver disease from 2007 through 2016. Gastroenterology. 2018;155:1154-63.

12. Tapper EB, Parikh ND. Mortality due to cirrhosis and liver cancer in the United States, 1999-2016: observational study. BMJ. 2018;362:k2817.

13. Kim D, Li AA, Perumpail BJ, et al. Changing trends in etiology-based and ethnicity-based annual mortality rates of cirrhosis and hepatocellular carcinoma in the United States. Hepatology. 2019;69:1064-74.

14. Kim WR, Brown Jr RS, Terrault NA, El-Serag H. Burden of liver disease in the United States: summary of a workshop. Hepatology. 2002;36:227-42.

15. Vong S, Bell BP. Chronic liver disease mortality in the United States, 1990-1998. 2004;39:476-83.

16. Manos MM, Leyden WA, Murphy RC, Terrault NA, Bell BP. Limitations of conventionally derived chronic liver disease mortality rates: results of a comprehensive assessment. Hepatology. 2008;47:1150-

17. Asrani SK, Larson JJ, Yawn B, et al. Underestimation of liver-related mortality in the United States. Gastroenterology. 2013;145:375-82.e1-2.

18. Ly KN, Speers S, Klevens RM, et al. Measuring chronic liver disease mortality using an expanded cause of death definition and medical records in Connecticut, 2004. Hepatol Res. 2015;45:960-8.

19. Fedeli U, Schievano E, Lisiero M, Avossa F, Mastrangelo G, Saugo M. Descriptive epidemiology of chronic liver disease in northeastern Italy: an analysis of multiple causes of death. Popul Health Metr. 2013;11:20.

20. World Health Organization. ICD-10: International Statistical Classification of Diseases and Related Health Problems, Tenth Revision, Volume 2 Instruction Manual, Fifth Edition, 2016. Geneva: World Health Organization, 2016. Available from: https://icd.who.int/browse10/Content/statichtml/ICD10Volume2_en_2016.pdf

21. Israel RA, Rosenberg HM, Curtin LR. Analytical potential for multiple cause-of-death data. Am J Epidemiol. 1986;124:161-79.

22. Goldacre MJ. Cause-specific mortality: understanding uncertain tips of the disease iceberg. J Epidemiol Comm Health. 1993;47:491-6.

23. Redelings MD, Sorvillo F, Simon P. A comparison of underlying cause and multiple causes of death: US vital statistics, 20002001. Epidemiology. 2006;17:100-3.

24. Fedeli U, Avossa F, Guzzinati S, Bovo E, Saugo M. (2014). Trends in mortality from chronic liver disease. Ann Epidemiol. 2014;24:522-6. 
25. Desequelles A, Demuru E, Egidi V, et al. Cause-specific morality analysis: in the underlying cause of death sufficient? Quetelet J. 2014;2:119-35.

26. Piffaretti C, Moreno-Betancur M, Lamarche-Vadel A, et al. Quantifying cause-related mortality by weighting multiple causes of death. Bull World Health Organ. 2016;94:870-9.

27. Fedeli U, Grande E, Grippo F, Frova L. Mortality associated with hepatitis C and hepatitis B virus infection: A nationwide study on multiple causes of death data. World J Gastroenterol. 2017;23:1866-71.

28. Batty, G. D., Gale, C. R., Kivimäki, M., \& Bell, S. Assessment of relative utility of underlying vs contributory causes of death. JAMA Netw Open. 2019;2:e198024.

29. Cardona K and Maithel SK eds. Primary and Metastatic Liver Tumors: Treatment Strategy and Evolving Therapies. Switzerland: Springer Nature, 2018.

30. Mahvi DA., Mahvi DM. Liver Metastases. In Niederhuber, John E. ed. Abeloff's Clinical Oncology, the Six Edition, Philadelphia: Elsevier, Inc. 2020; 846-62.

31. Center for Disease Control and Prevention. Wide-ranging ONline Data for Epidemiologic Research (CDC WONDER): Multiple Cause of Death Data. https://wonder.cdc.gov/mcd.html Accessed at April 4th, 2020.

32. Pinheiro PS, Callahan KE, Jones PD, et al. Liver cancer: a leading cause of cancer death in the United States and the role of the 1945-1965 birth cohort by ethnicity. JHEP Rep. 2019;1:162-9.

33. Zheng Z, Chen C, Jiang L, et al. Incidence and risk factors of gastrointestinal neuroendocrine neoplasm metastasis in liver, lung, bone, and brain: A population-based study. Cancer Med. 2019;8:7288-98.

34. Xie J, Xu, Z. A population-based study on liver metastases in women with newly diagnosed breast cancer. Cancer Epidemiol Biomarkers Prev. 2019;28:283-92.

35. Siebenhüner AR, Güller U, Warschkow R. (2020). Population-based SEER analysis of survival in colorectal cancer patients with or without resection of lung and liver metastases. BMC Cancer. 2020;20:1-9.

36. Smith BD, Morgan RL, Beckett GA, et al. Recommendations for the identification of chronic hepatitis $\mathrm{C}$ virus infection among persons born during 1945-1965. MMWR Recomm Rep.2012;61:1-32.

37. National Center for Health Statistics. Physicians' Handbook on Medical Certification of Death. Hyattsville, MD: US Department of Health and Human Services; 1987.

38. Cotter T, Charlton M. The triumph of Bacchus: the emergence of nonalcoholic steatohepatitis and alcoholic liver disease as the leading causes of mortality from cirrhosis. 2019;69:931-3.

39. Saviano A, Baumert TF. Mortality from liver cirrhosis and HCC in the DAA era: success in viral control is darkened by raise of metabolic disease. Hepatobiliary Surg Nutr. 2019;8:307-10.

\section{Figures}

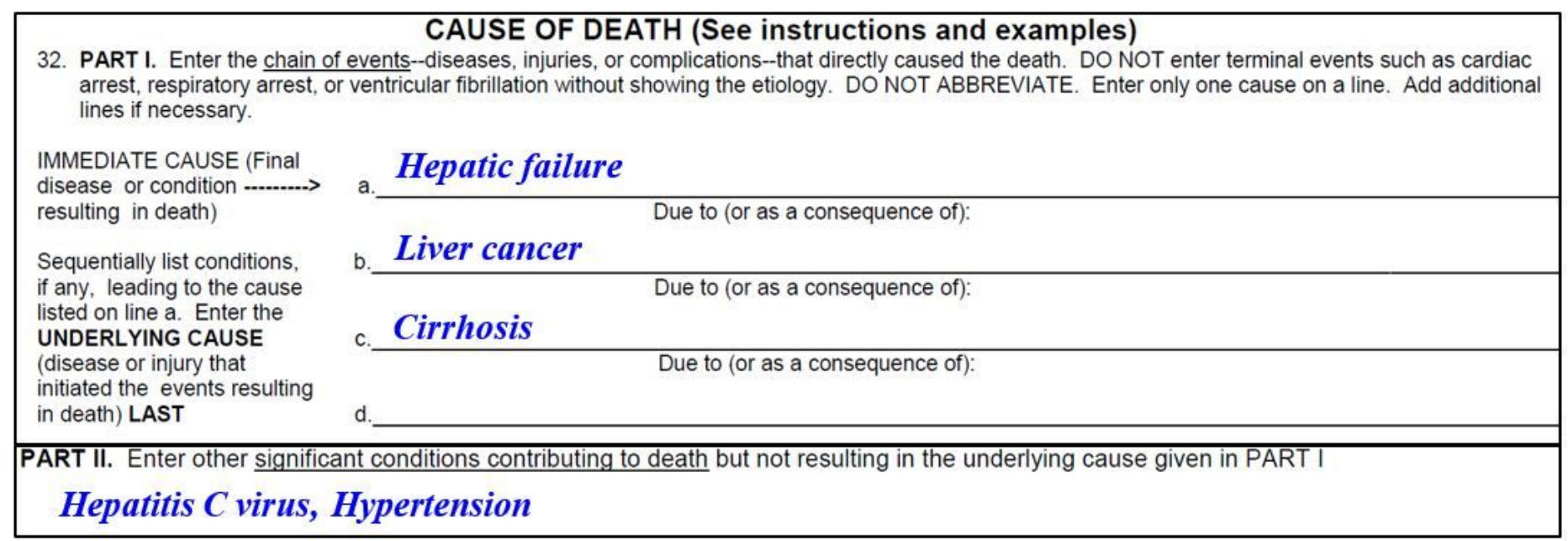




\section{Figure 1}

The certifying physician recorded four liver-related diagnoses on the death certificate. Only "liver cancer" would be selected as the underlying cause of death for mortality tabulation.

\section{Multiple causes of death}

Rate diff. Rate ratio

2018-2008 2018/2008

$-0.88 \quad 0.86$

$-0.10 \quad 0.90$

$\begin{array}{ll}3.05 & 1.37\end{array}$

$1.42 \quad 1.22$

$\begin{array}{ll}2.24 & 1.27\end{array}$

$3.67 \quad 1.49$

$0.24 \quad 1.22$

2.37

$-0.72$

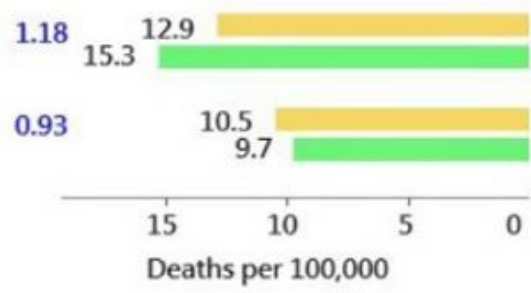

5.6

8.2

11.2

0.9
Underlying cause of death
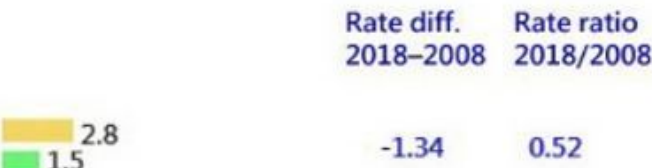

1.0 Other hepatitis

Alcoholic liver

disease

Other diseases of

liver

Primary liver

cancer

Secondary liver

cancer

Esophageal varices

Cirrhosis

Hepatic failure$$
-1.34
$$

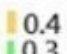

0.4
0.3
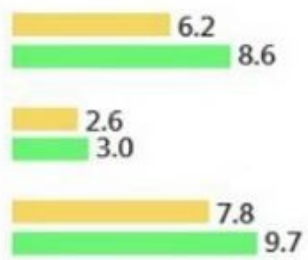

1.90

0.9
0.7

0.1

0.1

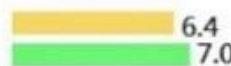

7.0

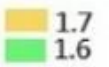

0.96

\begin{tabular}{lccc}
\hline 0 & 5 & 10 & 15 \\
& Deaths per & 100,000 &
\end{tabular}

\section{Figure 2}

Absolute (rate difference) and relative (rate ratio) change in the expanded definition of liver-related mortality rates (deaths per 100,000) from 2008 to 2018 according to underlying cause of death versus those based on multiple cause of death data in the United States. https://public.tableau.com/profile/robert.lu\#!/vizhome/20072017USA/Liver-relatedmortality 